\title{
SEISMIC VULNERABILITY OF REINFORCED CONCRETE BRIDGES IN PAKISTAN
}

\author{
Muhammad Khalid HAFIZ ${ }^{1 *}$, Qaiser-uz-Zaman KHAN ${ }^{1}$, Sohaib AHMAD ${ }^{2}$ \\ ${ }^{1}$ Department of Civil Engineering, University of Engineering and Technology, Taxila, Pakistan \\ ${ }^{2}$ Works and Services Organization, Islamabad, Pakistan
}

Received 30 November 2020; accepted 23 September 2021

\begin{abstract}
Different researchers have performed seismic hazard assessment studies for Pakistan using faults sources which differ from Building Code of Pakistan (BCP 2007) with diverse standard deviations. The results of seismic hazard studies indicate that $\mathrm{BCP}$ requires gross revision considering micro and macro level investigations. The recent earthquakes in Pakistan also damaged bridge structures and some studies have been conducted by different researchers to investigate capacity of existing bridges.

The most of bridge stock in Pakistan has been designed assuming seismic loads as $2 \%, 4 \%$ and $6 \%$ of dead loads following West Pakistan Code of Practice for Highway Bridges. The capacity of eight selected real bridges, two from each seismic zone 2A, 2B, 3 \& 4 is checked against BCP demands. Static and dynamic analyses were performed and the piers were checked for elastic limits. It is established that piers are on lower side in capacity and the bridges in zone $2 \mathrm{~A}$ are generally less vulnerable. Whereas the bridges in zone $2 \mathrm{~B}, 3$ and 4 are vulnerable from medium to very high level. Hence, an in-depth analytical vulnerability study of bridge stock particularly in high-risk zone needs to be conducted on priority and appropriate seismic retrofitting schemes need to be proposed.
\end{abstract}

Keywords: hazard, vulnerability, seismic, bridges, piers, tectonics, Building Code of Pakistan.

\section{Introduction}

The collision of Indian plate with Eurasian plate is core reason for the creation of the Himalayan Ranges. The resulting thrusts, folds, bends and spinning actions along with transformation of the Indian Plate produced lateral slippage on the left in Balochistan. The Sulaiman range and the Northwestern Himalayan $(\mathrm{NH})$ range are the key dynamic fold belts-and-also thrust belts in Pakistan geographical environment. Active fault lines alongside Himalayan range have generated numerous seismic activities due to a "missing slip" in the Himalayas (Quittmeyer \& Jacob, 1979). Out of various, Main Mantle Thrust (MMT) and Main Boundary Thrust (MBT), are the major thrusts the $\mathrm{NH}$ range contains, and these have been sources of some significant earthquake activities in Pakistan.

Pakistan is situated in an earthquake prone region and has a history of devastating earthquake events. Seismic characteristics of this region are linked with major tectonic features and geology of the area. A chronological earthquake calendar composed by the Pakistan Meteorological Department [PMD] and NORSAR (Norway) (2007) de- scribes the seismic activity in the region. After the incident of the Kashmir Earthquake $\left(8^{\text {th }}\right.$ October 2005) in Pakistan, seismic hazard maps and seismic zoning has been modified and new Building Code of Pakistan (BCP 2007) (Ministry of Housing and Works, 2007) was adopted. Recently a number of researchers have performed peak Ground Acceleration (PGA) value studies for Pakistan using latest developments in the procedures. The values given by each researcher differ from those of Building Code of Pakistan (BCP) with diverse standard deviations for different cities of Pakistan.

Pakistan national road network has more than 8000 bridge structures spreading throughout the country. More than ninety-five percent of these bridges in Pakistan are Reinforced concrete (RC) bridges. Mostly, existing RC bridges in Pakistan built prior to Kashmir Earthquake (2005) lack sufficient strength and ductility to account for the present seismic demand requirements. Bridges in Pakistan have been designed according to Government of West Pakistan Code of Practice for Highway Bridges

*Corresponding author. E-mail: raomkhafeez@gmail.com 
(WPCPHB) (Highway Department, Government of West Pakistan Lahore, 1967) in which the seismic requirements were not very stringent. BCP SP-2007 was enforced but WPCPHB still requires attention. Some bridge investigations have been conducted by different researchers on existing RC bridges in Karachi (Southern Pakistan) and in Northern areas of Pakistan to evaluate their strength and capacity.

The current study focuses on evaluating the seismic hazard of existing Bridges in Pakistan based on Post Kashmir earthquake studies. The outcome of new seismic hazard studies of different researchers is identified. Seismicity damages caused to bridges in recent major earthquakes are presented. The bridge stock in Pakistan is considered for evaluating its capacity. Seismic vulnerability of existing RC bridge stock in central and north eastern Pakistan is defined based on the seismic demand calculation of eight selected existing RC bridge structures from these areas, two for each of four seismic zones, 2A, 2B, 3 \& 4. Equivalent Seismic demand of bridge piers (being the most vulnerable elements) corresponding to modified seismic loads and as per WPCPHB (Highway Department, Government of West Pakistan Lahore, 1967) are calculated to evaluate vulnerability.

\section{Seismic hazard studies of Pakistan}

Pakistan and its surrounding regions have active tectonic settings. Due to this fact, numerous seismic susceptibility researches have recently been concluded. While these works contain chronological and instrumentally recorded earthquakes, each encompasses some theoretically restrictive conventions concerning classification of seismic source areas and seismic catalogue formulation. The significant features of these studies are summarized in Table 1.

\subsection{Outcome of seismic hazard studies}

Ground motion estimations studies for Pakistan in terms of Peak Ground Acceleration (PGA) standards have been summarized above. These were carried out considering $10 \%$ likelihood of exceedance in 50 years with seismic risk maps in terms of $g$ value. A comparison of PGA with minimum, maximum and mean values of some cities of Pakistan estimated by the researchers cited above was made, the standard deviation and covariance values calculated are presented in the Table 2 .

The range of these PGA values in Table 2 shows significant variation in estimation of PGA values. Therefore, uncertainty in Peak Ground Acceleration values at different

Table 1. Summary of the key features of recent seismic hazard studies in Pakistan

\begin{tabular}{|c|c|c|}
\hline $\begin{array}{l}\text { Sr. } \\
\text { No }\end{array}$ & $\begin{array}{l}\text { Researcher / } \\
\text { Institute }\end{array}$ & Significant features \\
\hline 1 & $\begin{array}{l}\text { PMD and } \\
\text { NORSAR } \\
(2006)\end{array}$ & $\begin{array}{l}\text { Azad Kashmir and northern Pakistan areas were considered for earthquake risk. } \\
\text { Probabilistic Seismic Hazard Analysis (PSHA) methodology was adopted by distributing the area into sixteen } \\
\text { diffuse source regions. } \\
\text { Database with } \mathrm{M}_{\mathrm{w}} \geq 4.5 \text { was composed from organizations around the world } \\
\text { The Peak Ground Accelerations (PGA) for reoccurrence times of } 500 \text { and } 1000 \text { years for Islamabad are } 20 \% \text { of } \\
\text { gravity (g) and } 26 \% \text { of g, and for Muzaffarabad are } 20 \% \text { of g and } 31 \% \text { of g, respectively. }\end{array}$ \\
\hline 2 & $\begin{array}{l}\text { MonaLisa } \\
\text { et al. (2007) }\end{array}$ & $\begin{array}{l}\text { Computed seismic hazard for the NW Himalayan belt for ten towns, comprising Islamabad and Muzaffarabad. } \\
\text { PSHA methodology was used and region was divided into } 4 \text { seismic source regions. Database was with Mw } \\
\geq 4 \text { and had earthquakes events which were recorded with instruments and was taken from the International } \\
\text { Seismological Centre (ISC) and U.S. Geological Survey (USGS). } \\
\text { Attenuation equations anticipated PGA with } 475 \text {-year of return for Islamabad as } 10 \% \text { of gravity despite Islamabad } \\
\text { is situated at less than four kilometer of the seismically-dynamic MBT. Likewise, PGA is } 12 \% \text { of gravity for } \\
\text { Muzaffarabad, in spite of its closeness to the live Jhelum Fault and Riasi Thrust. }\end{array}$ \\
\hline 3 & $\begin{array}{l}\text { Ministry of } \\
\text { Housing and } \\
\text { Works (2007) }\end{array}$ & $\begin{array}{l}\text { Earthquake hazard analysis of Pakistan was made for seismic hazard mapping for Building Codes using PSHA } \\
\text { procedures based on grid points related to the } 475 \text { years reoccurrence age and } 10 \% \text { possibility of exceedance in } \\
50 \text { years. } \\
\text { Contours of PGA at } 0.1 \text { degree interval were plotted resulting seismic hazard maps. } \\
\text { Following Uniform Building Code (International Conference of Building Officials, 1997) Five Seismic Zones } \\
\text { were established for Pakistan. The limits of each zone are demarcated with the following PGA ranges: } \\
\text { Zone } 1 \quad 0.05 \text { to } 0.08 \mathrm{~g} \\
\text { Zone } 2 \mathrm{~A} \quad 0.08 \text { to } 0.16 \mathrm{~g} \\
\text { Zone } 2 \mathrm{~B} \quad 0.16 \text { to } 0.24 \mathrm{~g} \\
\text { Zone } 3 \quad 0.24 \text { to } 0.32 \mathrm{~g} \\
\text { Zone } 4 \quad>0.32 \mathrm{~g}\end{array}$ \\
\hline 4 & $\begin{array}{l}\text { Global } \\
\text { Seismic } \\
\text { Hazard } \\
\text { Assessment } \\
\text { Program } \\
\text { (1999) }\end{array}$ & $\begin{array}{l}\text { The United Nations, in the Global Seismic Hazard Assessment Program (GSHAP) coordinated seismic hazard } \\
\text { evaluation of the whole earth. } \\
\text { Consistent with a reoccurrence age of } 475 \text { years the GSHAP Universal Atlas of Seismic Risk portrays PGA with } \\
10 \% \text { probability of exceedance in } 50 \text { years. } \\
\text { International Plot of Seismic Risk with local grades containing Pakistan were printed in } 1999 .\end{array}$ \\
\hline
\end{tabular}


End of Table 1

\begin{tabular}{|c|c|c|c|c|c|c|}
\hline $\begin{array}{l}\text { Sr. } \\
\text { No }\end{array}$ & & \multicolumn{5}{|c|}{ Significant features } \\
\hline \multirow[t]{3}{*}{5} & \multirow[t]{3}{*}{$\begin{array}{l}\text { International } \\
\text { Conference } \\
\text { of Building } \\
\text { Officials } \\
(1997)\end{array}$} & \multicolumn{5}{|c|}{$\begin{array}{l}\text { Uniform Building Code (UBC-97) (International Conference of Building Officials, 1997) presented Seismic } \\
\text { Design Procedure. } \\
\text { Seismic risk features for the site were to be established based on the outlines given in the Code. } \\
\text { Five seismic zones, zone } 1,2 \mathrm{~A}, 2 \mathrm{~B}, 3 \text { and } 4 \text { with zone factors as } 0.075 \mathrm{~g}, 0.15 \mathrm{~g}, 0.2 \mathrm{~g}, 0.3 \mathrm{~g} \text { and } 0.4 \mathrm{~g} \text { respectively } \\
\text { were defined and compiled the zoning map for USA. This compilation has a listing of seismic zones for } 4 \\
\text { Pakistani cities. } \\
\text { Seismic Zone tabulation as per Division III of Appendix to Chapter-16 of UBC-97 is: }\end{array}$} \\
\hline & & Cities & ISLAMABAD & AHORE & KARACH & \\
\hline & & UBC-97 & & & & \\
\hline 6 & & \multicolumn{5}{|c|}{$\begin{array}{l}\text { Seismic hazard assessment of Pakistan was carried out by PSHA procedure. } \\
\text { Existing earthquake catalogues of Pakistan were upgraded adding instrumental earthquake records from } 1902 \text { to } \\
\text { 2009. The assessment was established on the most modernized ground motion prediction equations (GMPEs). } \\
\text { The final result of this calculation consisted of seismic risk plots for PGA with possibilities of exceedance in } 50 \\
\text { years as } 10 \% \text { and } 2 \% \text {. }\end{array}$} \\
\hline 7 & & \multicolumn{5}{|c|}{$\begin{array}{l}\text { The methodology of seismic hazard analysis included identification of seismic sources from } 32 \text { faults in NW } \\
\text { Pakistan. } \\
\text { Characterization of recurrence models for the faults was based on both historical and instrumented seismicity } \\
\text { in addition to geologic evidence. } \\
\text { Peak ground accelerations for Kaghan and Muzaffarabad which are surrounded by major faults were predicted to } \\
\text { be approximately } 3 \text { to } 4 \text { times greater than estimates by previous studies using diffuse areal source zones. Seismic } \\
\text { hazard maps for PGA and spectral accelerations at periods of } 0.2 \mathrm{sec} \text { and } 1.0 \mathrm{sec} \text { corresponding to } 475-\text {-, 975-, and } \\
2475 \text {-year return periods were produced for NW Pakistan. }\end{array}$} \\
\hline 8 & & \multicolumn{5}{|c|}{$\begin{array}{l}\text { An earthquake of magnitude } 6.5 \mathrm{Mb} \text { occurred on } 29 \text { October } 2008 \text { near Chiltan hills, Balochistan Province, in } \\
\text { Pakistan with a foreshock of magnitude } 5.0 \mathrm{Mb} \text {. Depths of events were } 15 \text { and } 12 \mathrm{~km} \text {, respectively. } \\
\text { For this study, } 1,185 \text { aftershocks ranging from } 2.2 \text { to } 4.8 \mathrm{Mb} \text { were recorded till end of January } 2009 \text { using four } \\
\text { portable instruments. } \\
\text { The source mechanism was found to be strike slip which disagreed with the existing description of the fault } \\
\text { system in the area which was previously thought to be thrust in nature. }\end{array}$} \\
\hline 9 & & \multicolumn{5}{|c|}{$\begin{array}{l}\text { Seismo-tectonics and Seismic Hazard Analysis of Simly Dam Project Islamabad were conducted. The deterministic } \\
\text { and Probabilistic hazard study was carried out for the capital area of Pakistan, Islamabad, by considering Earth } \\
\text { quake source zones. } \\
\text { It was concluded that after Kashmir Hazara Earth quake, reactivated critical tectonic features in this zone are, the } \\
\text { Muzaffarabad Thrust Fault (MTF), the Darband Fault and the Jhelum Fault. } \\
\text { Considering MBT and Indus Kohistan Seismic Zone (IKSZ) the PGA value of } 0.45 \mathrm{~g} \text { and } 0.38 \mathrm{~g} \text { have been } \\
\text { calculated with } 10 \% \text { probability of exceedance in } 50 \text { years. }\end{array}$} \\
\hline 10 & & \multicolumn{5}{|c|}{$\begin{array}{l}\text { Historic seismic record was incorporated with instrumentally noted earthquake data to conclude elongated } \\
\text { period risk. The effect of tectonic characteristic of the area was involved by taking care of seismic source zones } \\
\text { linked with identified key fault lines. Monte-Carlo simulations technique was employed to produce artificial } \\
\text { earthquake event strings with randomized important risk factors. The suggested PSHA methodology was verified } \\
\text { using Pakistan as a case study. } \\
\text { The outcomes of this work matched finely with the Pakistan Building Code risk map, although these results } \\
\text { presented additional and complete local risk dissemination. }\end{array}$} \\
\hline 11 & & \multicolumn{5}{|c|}{$\begin{array}{l}\text { Peshawar has been placed in seismic zone 2B with a PGA range of } 0.16-0.24 \text { in BCP 2007. A PSHA technique } \\
\text { was used to estimate the ground motion for a grid of } 11 \mathrm{~km} \text { by } 11 \mathrm{~km} \text {, covering all the active faults within and } \\
\text { around the Peshawar region. PGA along with spectral acceleration values as required by IBC } 2009 \text { and ASCE- } 7 \\
\text { was calculated. It was found that Peshawar lies in seismic Zone } 1 \text { with a PGA value of } 0.06 \text {. The estimated PGA } \\
\text { value was also validated and in line with the PGA values obtained from the ground motion records of Peshawar } \\
\text { Meteorological Department. }\end{array}$} \\
\hline 12 & & \multicolumn{5}{|c|}{$\begin{array}{l}\text { This study is based on a new compilation of active faults and seismic sources definitions. This research includes } \\
\text { all available statistics on historical earthquakes with a re-assessment of seismic hazard for Karachi using } \\
\text { probabilistic and deterministic seismic hazard assessment approaches. Karachi is assessed to be prone to ground } \\
\text { motions } \sim 0.25 \mathrm{~g} \text { with metropolitan areas having hazard values between } 0.21 \text { and } 0.25 \mathrm{~g} \text { for } 10 \% \text { probability of } \\
\text { exceedance in } 50 \text { years. }\end{array}$} \\
\hline 13 & & \multicolumn{5}{|c|}{$\begin{array}{l}\text { For PSHA of Pakistan the standard Cornell-McGuire (1968-1976) methodology is used, and the calculations are } \\
\text { made over a rectangular grid of } 0.1^{\circ} \text { with recent data. } \\
\text { Results of the study show that seismic hazard in Pakistan is highest in its central and northern parts. In the } \\
\text { central part near Quetta, severe seismic hazard (PGA } 0.40 \mathrm{~g} \text { ) is observed, for Balakot city value of } 0.36 \mathrm{~g} \text {, while } \\
\text { for Islamabad, Peshawar and Chitral are likely to experience } 0.33 \mathrm{~g} \text {. The cities of Gilgit, Karachi and Gwadar } \\
\text { experience ground motion values of } 0.34,0.26 \text { and } 0.29 \mathrm{~g} \text {, respectively, for the } 475 \text {-year return period. The hazard } \\
\text { map presented in this study is the improved seismic hazard zoning map of Pakistan. It is established that the } \\
\text { seismic zoning map of the national seismic design code of Pakistan underestimates the ground motion values, } \\
\text { and it should be updated or replaced. }\end{array}$} \\
\hline
\end{tabular}


Table 2. Maximum and minimum estimated PGA (g) with standard deviation and Covariance for different researcher for some cities of Pakistan

\begin{tabular}{|l|c|c|c|c|c|c|c|}
\hline \multicolumn{1}{|c|}{ Cities } & Islamabad & Lahore & Peshawar & Karachi & Quetta & Gwadar & Muzaffarabad \\
\hline Max. PGA (g) & 0.45 & 0.30 & 0.45 & 0.55 & 0.50 & 0.71 & 0.45 \\
\hline Min. PGA (g) & 0.24 & 0.15 & 0.06 & 0.10 & 0.30 & 0.20 & 0.25 \\
\hline Mean PGA (g) & 0.307 & 0.195 & 0.247 & 0.263 & 0.400 & 0.375 & 0.375 \\
\hline Standard deviation & 0.075 & 0.058 & 0.121 & 0.130 & 0.065 & 0.177 & 0.069 \\
\hline Covariance & 0.245 & 0.295 & 0.489 & 0.497 & 0.161 & 0.472 & 0.184 \\
\hline
\end{tabular}

locations in Pakistan needs to be addressed particularly in seismic fragility and risk assessment studies. The BCP 2007 also needs an in depth review considering all of recent micro and macro level researches in Pakistan for its revision.

\section{Bridge stock in Pakistan}

The total road-network in Pakistan is $270,971 \mathrm{~km}$, which includes 47 national highways, motorways, expressways, and planned roadways having span of $12,743 \mathrm{~km}$. The remaining road system comprises provincial level roads and the arteries under corresponding local governments (Economic Adviser's Wing, Finance Division, 2019). The total national road network has more than 8000 bridge structures spreading throughout the country. National highways are the spine of Pakistan's transport system and encompass significant share in the growth of micro and macro economy of the country. Thus, every bridge structure on these highways is of vital importance. More than ninety-five percent of these bridges in Pakistan are Reinforced concrete (R.C.) bridges. Structural system of maxi- mum of theses R.C. bridges in Pakistan typically consists of superstructure of pre-stressed / cast in situ R.C. girders with deck slab resting on cast in place transom built on R.C. piers erected on pile cap with pile foundation underneath. Thus, the piers act as inverted pendulum and are most vulnerable part of bridge structure.

Figure 1 describes the location of some bridges marked on map showing their proximity with respect to the seismic zones. It is important that some of these bridges are very close to fault lines as Raikot fault of MMT is passing through the abutment of Raikot Bridge on Indus River on $\mathrm{N}-35$, the Karakorum Highway (KKH).

\section{Seismic hazard studies of bridges in Pakistan}

The revision of BCP 2007 has upgraded the seismic zones of almost every city of Pakistan putting them into higher seismic prone areas. The bridges constructed before October 2005 were in accordance with WPCPHB (Highway Department, Government of West Pakistan Lahore, 1967). Different researchers worked to ascertain the potential of

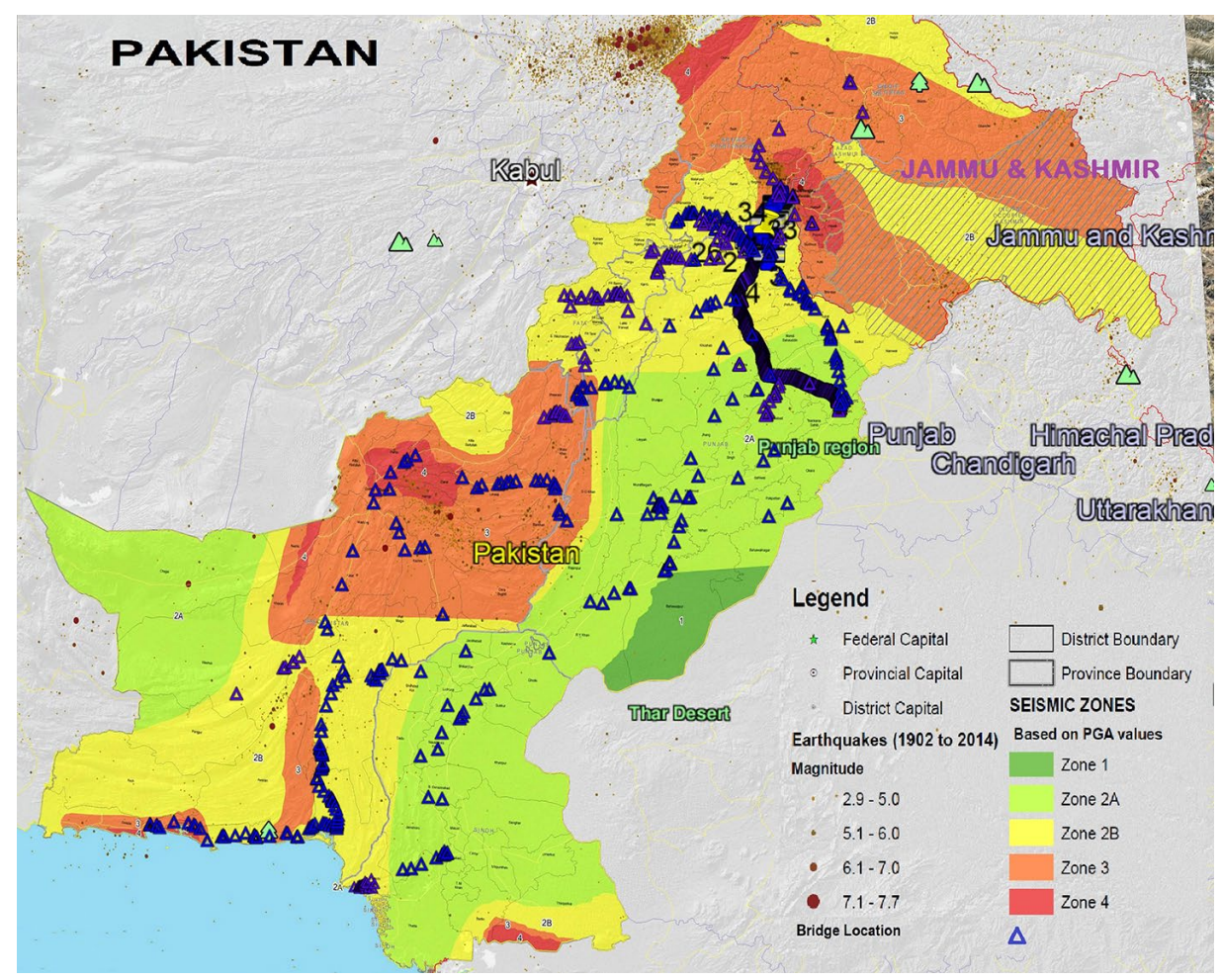

Figure 1. Scattered bridge stock super imposed on BCP 2007 (Ministry of Housing and Works, 2007) seismic zoning 
existing bridges to resist the revised earthquake demands. Ali et al. (2011) conducted a survey of damages to Bridges in Pakistan after the major earthquake of 8 October 2005. The survey was carried out on around $400 \mathrm{~km}$ road network and 90 bridges were inspected for earthquake related damages. It was observed that out of these, 14 bridges or $16 \%$ had damages of varying degree out of which 9 bridges or $10 \%$ were either failed or became non functional. The study reported the prominent types of failures observed and discussed design deficiencies in design procedures. This survey highlighted the deficiencies in construction practices in Pakistan and pointed out the need for improvement in bridge design practices.

Khan et al. (2015) conducted the studies to assess vulnerability of existing bridges to the seismic ground motion in Karachi, Pakistan. Physical surveys were conducted to collect the data about bridges and their structural systems. Three types of piers were identified for the bridges. Each type was further divided into three classes based on the cross-sectional shape or dimensions. As a result, numerical analysis was conducted on a total of nine bridge types. Fragility curves for each bridge type were also plotted. Damage estimation using the numerical models of the bridges corresponding to 150-, 475- and 1000-year return periods was made. Most of the bridges and flyovers were able to resist ground shaking due to mild earthquakes without any significant damage. On the other hand, damages of different grades were noted in the bridges and flyovers in case of moderate and large earthquakes. It was found that a significant number of bridges may not be able to resist a large magnitude earthquake and may either be collapsed or extensively damaged.

Waseem and Spacone (2017) presented seismic vulnerability assessment of three real case simply supported multi-span reinforced concrete bridges commonly found in northern Pakistan, having one, two and three bents with circular piers. The vulnerability assessment is carried out through the non-linear dynamic time history analyses for the derivation of fragility curves. Seismic responses of shear key, bearing pad, expansion joint and pier components of each bridge were recorded during analysis and retrieved for performance based analysis. Fragility curves were developed for the bearing pads, shear key, expansion joint and pier of the bridges that first reach ultimate limit state. Dynamic analysis and the derived fragility curves show that ultimate limit state of bearing pads, shear keys and expansion joints of the bridges exceed first, followed by the piers ultimate limit state for all the three bridges. Mean collapse capacities computed for all the components indicated that bearing pads, expansion joints, and shear keys exceed the ultimate limit state at lowest seismic intensities.

\section{Bridge damages in recent earth quake events in Pakistan}

The earthquake environments are composite in the Pakistan area. With the blend of background seismicity, highest seismo-genic sources for an earthquake in Pakistan are crustal faults and subduction zone. The frequency of earthquakes in and around Pakistan is very high. The seismicity map of Pakistan for the year 2019 (Figure 2), prepared by PMD shows the trends of activity throughout Pakistan with Earth quakes M 5-5.9 are in the proximity of major fault lines.

\subsection{Kashmir Earthquake (2005)}

On October 08, 2005 the Kashmir earthquake shaken Pakistan-administered Azad Jammu and Kashmir (AJK). It had epicentre in the vicinity of Muzaffarabad and it severely damaged AJK, Khyber Pakhtunkhwa (KPK) province and Indian-administered Jammu and Kashmir. Its moment magnitude ' $\mathrm{M}_{\mathrm{w}}$ ' was 7.6 and PGA at epicentre was up to $175 \%$ of gravity (1.75 g) (Figure 3, U.S. Geological Survey, USGS) and maximum intensity on Mercalli scale was VIII. The shockwaves also caused disorder in Afghanistan, Tajikistan and Chinese Xinjiang.

In this earthquake 73,338 people lost their lives. The infrastructure setup and communication systems in 30,000 sq. km of area was completely destructed in the event.

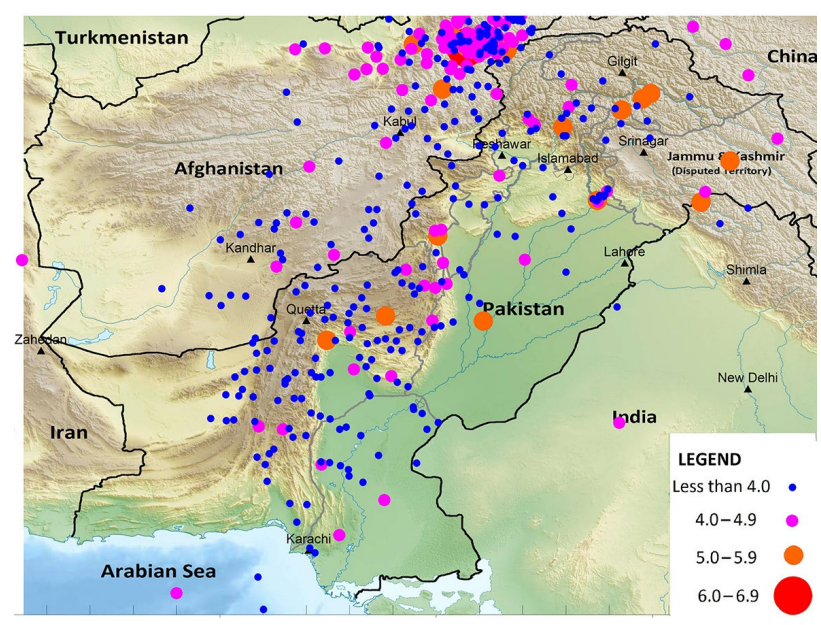

Figure 2. The seismicity map of Pakistan for the year 2019 (PMD, 2019)

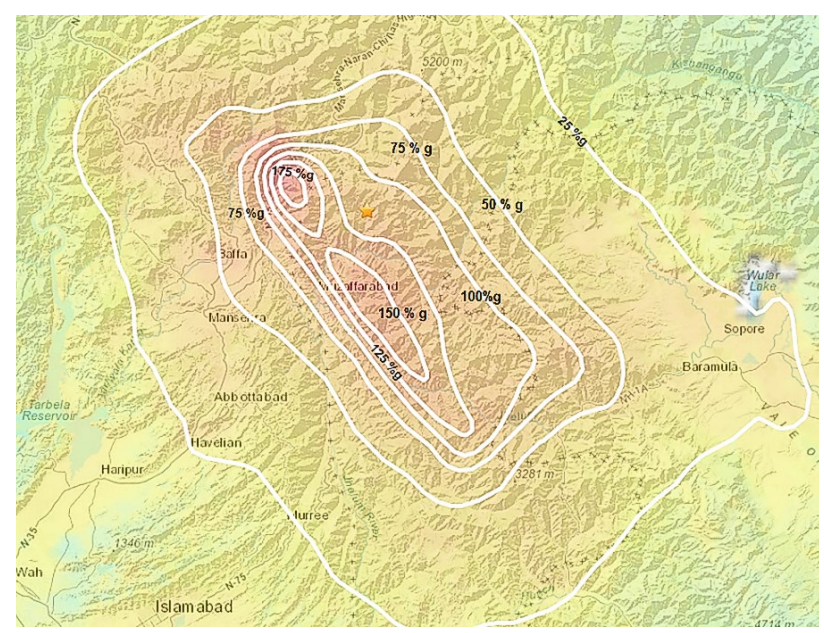

Figure 3. The PGA evaluated on 08 October 2005 of Kashmir Earthquake (USGS Earthquake Hazards Program, 2020) 


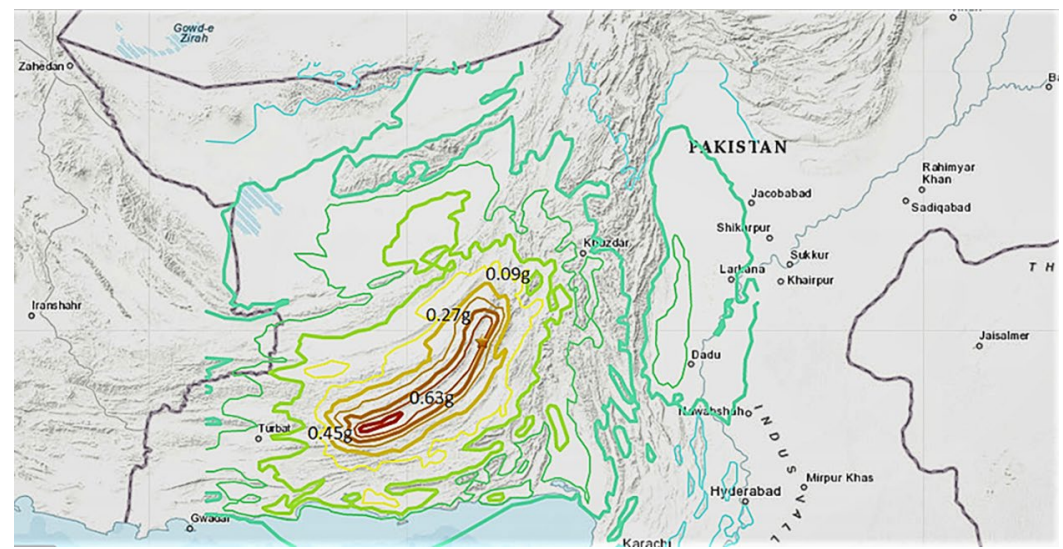

Figure 4. The PGA recorded on 28 September, 2013 of Awaran Earthquake (USGS Earthquake Hazards Program, 2020)

a)

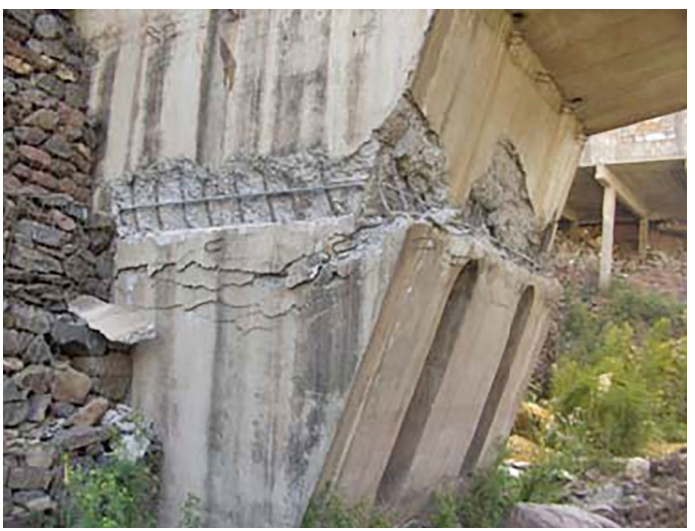

c)

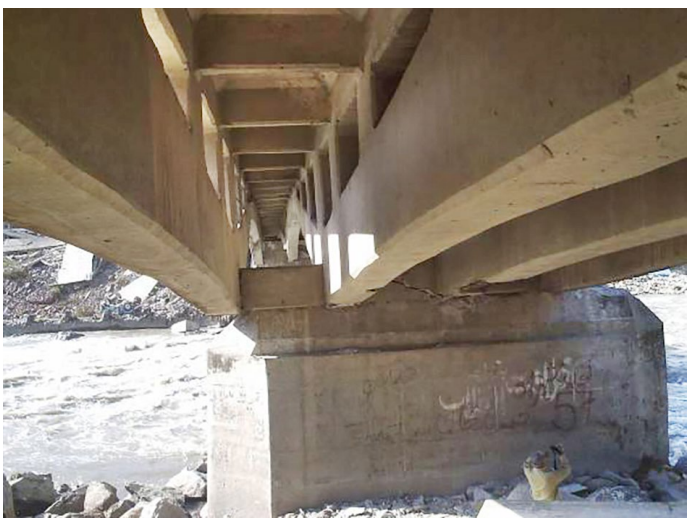

e)

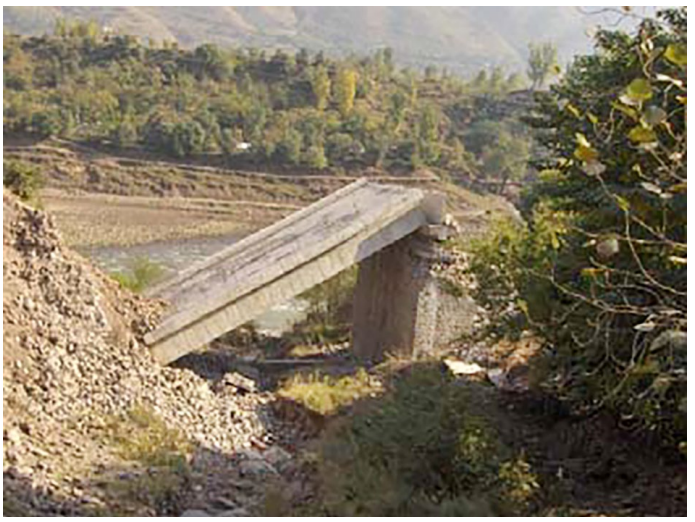

b)

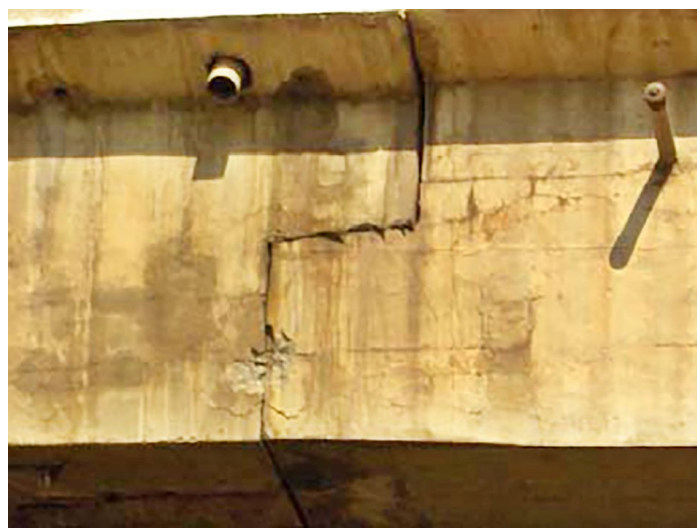

d)

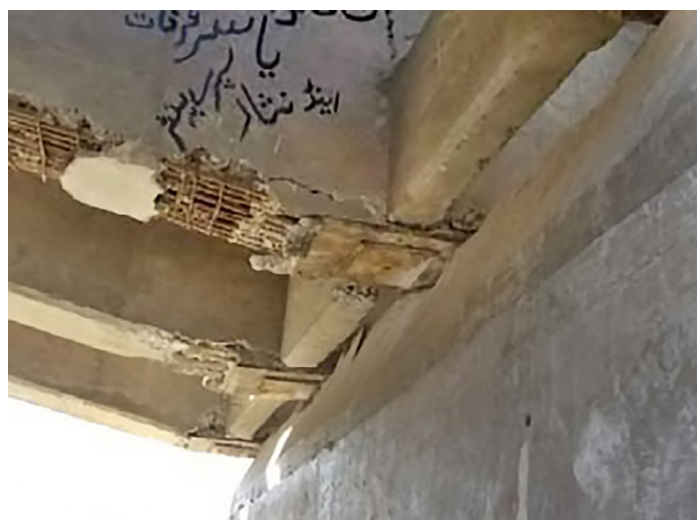

f)

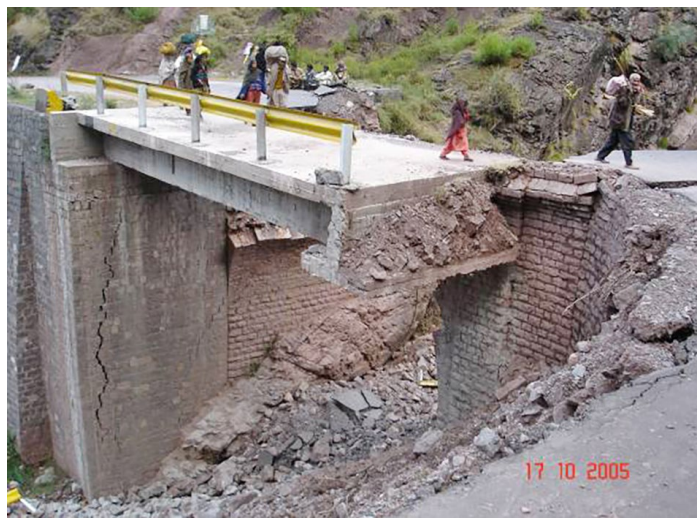

Figure 5. Some damages to bridges during 08 October, 2005 Kashmir earthquake: a - Severely damaged abutment, Garhi Dopata bridge; b - bridge pounding at expansion joint, Garhi Dopata; $\mathrm{c}$ - Balakot bridge over River Kunhar, Balakot City; d - Spalling \& cracks in Balakot bridge; e - Drop down of Sobrhi Bridge, Mzd Sri Nagar Road; $f$ - Abutment failure of a bridge in AK 
In the road sector $6,440 \mathrm{~km}$ of highways were severely damaged. A total of 35 key bridges required rebuilding while 137 small bridges, 143 culverts and pedestrian bridges required repair (Earthquake Reconstruction and Rehabilitation Authority [ERRA], 2006b). Pictures of some of the bridges damaged during this earthquake are illustrated in Figure 5 (ERRA, 2006a).

\subsection{Awaran Earthquake (2013)}

An earthquake of moment magnitude, $M_{w}$ of 7.7 with a focal depth of $10 \mathrm{~km}$ located in the Makran Accretionary Zone shocked the Southwestern province of Pakistan, Balochistan on 24 September, 2013. A main aftershock of moment magnitude $\mathrm{M}_{\mathrm{w}}$, of 7.2 followed the event on 28 September, 2013. The Peak Ground Acceleration documented by USGS in the area is shown in Figure 4. In this event 92 culvert bridges were damaged and $505 \mathrm{~km}$ of road structures were destructed (Information Management and Mine Action Programs [iMMAP], 2013).

\subsection{Mirpur Earthquake (2019)}

On 24 September 2019, a devastating earthquake shocked numerous parts of Pakistani Administered Jammu and Kashmir including areas of Punjab, and KPK. Jatlan area in Mirpur district, AJK was badly affected during this event. The US Geological Survey (USGS) reported its epicentre location at one kilometre SE of Mirpur city near Jatlan with a shallow depth of $10 \mathrm{~km}$ and having a moment magnitude of 5.8 (Figure 6). The total of 39 causalities were reported while residential structures, public buildings, bridges, roads, and other infrastructure in Mirpur district faced severe to moderate damages (National Disaster Management Authority [NDMA], 2019). Four bridges and the main road from Mirpur to Jatlan along Jatlan Canal were severely damaged. The damages of a Bridge on Jatlan canal are illustrated in Figure 7. A number of vehicles moving on the road when the earthquake hit the area were also badly smashed.

The recent history of earthquakes in Pakistan shows that there is a variation in actual PGA recorded verses PGA anticipated in BCP 2007, and is summarized in the Table 3 below.

Most of the bridges in Pakistan have been designed according to WPCPHB (Highway Department, Government of West Pakistan Lahore, 1967), the seismic requirements of which are now obsolete. The above studies and survey indicate that the seismic demands at many places in Pakistan are higher than those given in BCP 2007.

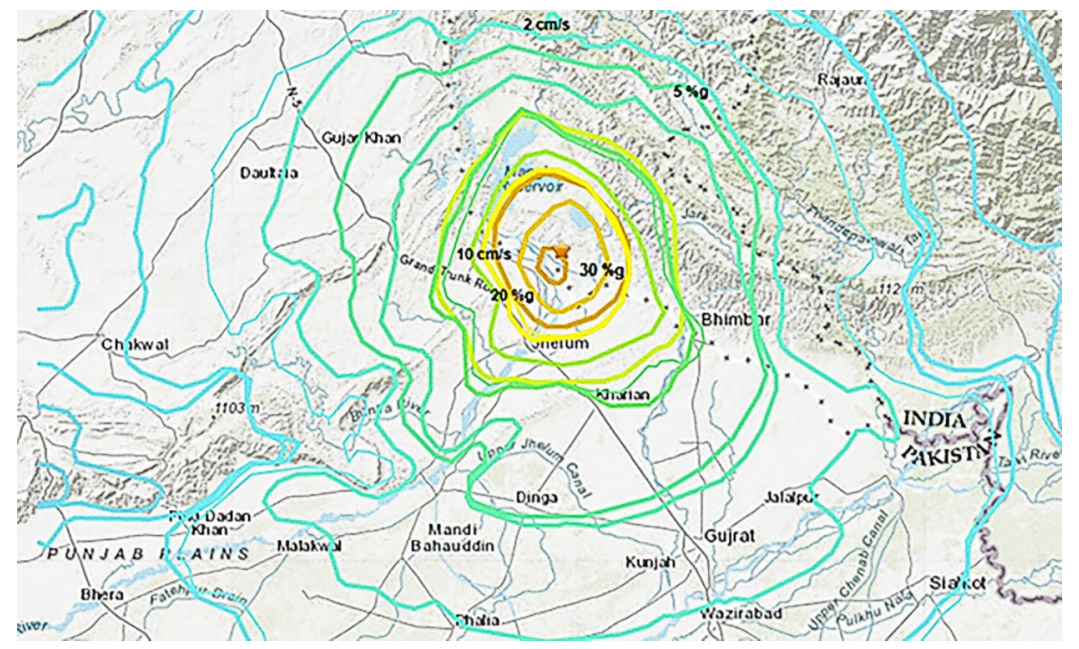

Figure 6. The PGA recorded on 24 September, 2019 of Jatlan Earthquake (USGS Earthquake Hazards Program, 2020)
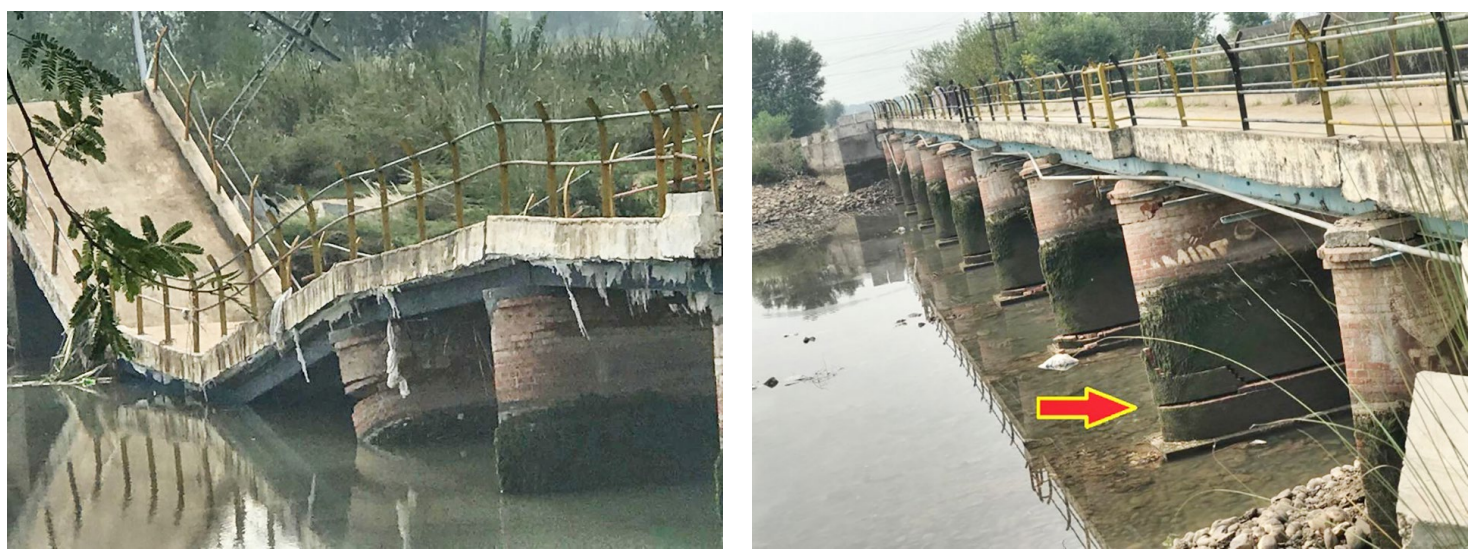

Figure 7. The damages of bridge on Jatlan canal during September 24, 2019 earthquake 
Table 3. Actual PGA (g) as reported by USGS/PMD cited with reference to PBC for recent events in Pakistan

\begin{tabular}{|c|l|c|c|c|c|}
\hline No. & \multicolumn{1}{|c|}{ Location } & \multicolumn{1}{|c|}{ Event } & $\begin{array}{c}\text { Zone as } \\
\text { per BCP 2007 }\end{array}$ & $\begin{array}{c}\text { Max. PGA as } \\
\text { per BCP 2007 (g) }\end{array}$ & $\begin{array}{c}\text { Actual PGA } \\
\text { occurred (g) }\end{array}$ \\
\hline 1 & Awaran-Mashkai & M 7.7 EQ, 24-09-2013 & 3 & 0.32 & 0.63 \\
\hline 2 & Mirpur- Jatalan & M 5.8 EQ 24-09-2019 & 2B & 0.24 & 0.319 \\
\hline 3 & Quetta & M 6.5 EQ 29-10-2008 & 3 & 0.32 & 0.173 \\
\hline
\end{tabular}

Thus, there is the requirement for investigation of all existing bridges, especially constructed before 2005 , to check the capacity of the structure at least as per seismic zoning of BCP 2007.

\section{Bridge design practices in Pakistan}

Since the creation of Pakistan in 1947 to 1970s, the country has employed British building codes, which did not incorporate any seismic provisions. After the 1935 earthquake, Quetta was the only city where seismic design requirements were established and imposed. Then subsequently, Uniform Building Code (International Conference of Building Officials, 1997) was accepted as an alternative until the International Building Code (IBC) substituted it. The seismic design requirements were present in both of these codes.

As Pakistan is lacked an indigenous seismic code for bridges, the bridge stock in Pakistan since 1967 has been designed as per WPCPHB assuming seismic loads as $2 \%$, $4 \%$ and $6 \%$ of dead loads for different foundation conditions. These assumptions do not match with the present day seismic demands and require great consideration.

In 1986, first national building code for Pakistan was printed as a recommended manuscript but was not truly acknowledged, imposed, or restructured. The shocking earthquake of October 08, 2005 necessitated that the seismic requirements of the Pakistan Building Code 1986 must be fundamentally strengthened. The necessity of these provisions was to introduce minimum measures for earthquake deliberations in building design and structural arrangements.

The BCP 2007 Seismic Provisions (Ministry of Housing and Works, 2007) are compatible with the USA's Uniform Building Code 1997 (International Conference of Building Officials, 1997), ACI 318-05 (American Concrete Institute [ACI], 2004), ANSI/AISC 341-05 (American Institute of Steel Construction, 2005), ASCE/SEI 7-05 (American Society of Civil Engineers [ASCE], 2006) and ANSI/ASCE 7-93 (ASCE, 1994).

\section{Seismic demand analysis for existing $\mathrm{RC}$ bridge piers in Pakistan}

The RC bridge stock surveyed was checked for the structural arrangement and it was noted that more than $90 \%$ of old bridges have circular pier bents. The number of spans ranged from one to 24 with span length varied from
$12.195 \mathrm{~m}$ (40 ft.) to $80.488 \mathrm{~m}$ ( $264 \mathrm{ft}$.$) . Around 10 \%$ of these bridges are cast in place RC beams with monolithical slabs. Remaining bridges have precast prestressed girders with prestressed or non prestressed slabs resting on cast in place transom built on R.C. piers erected on pile cap with pile or well foundation underneath. Thus, the piers act as inverted pendulum and are most vulnerable part of bridge structure. They have been designed for base shear, $6 \%$ of dead load which requires reconsideration when examined considering present seismic zoning requirements.

Total eight real bridges, two from each of seismic zone 2A, 2B, $3 \& 4$ were selected to be checked for seismic demand. The drawings from corresponding offices were got on special requests (Table 4).

Table 4. List of bridges selected for analysis in different seismic zones

\begin{tabular}{|c|l|c|c|}
\hline No. & \multicolumn{1}{|c|}{ Bridge location } & $\begin{array}{c}\text { Seismic } \\
\text { Zone }\end{array}$ & $\begin{array}{c}\text { PGA demand }(\mathrm{g}) \\
\text { as per BCP 2007 }\end{array}$ \\
\hline 1 & $\begin{array}{l}\text { Budhi Nullah near village } \\
\text { Daulatpur, Sargodha }\end{array}$ & $2 \mathrm{~A}$ & 0.14 \\
\hline 2 & Saggian Ravi River Lahore & $2 \mathrm{~A}$ & 0.14 \\
\hline 3 & $\begin{array}{l}\text { Dina-Rohtas Road near } \\
\text { Rohtas Fort }\end{array}$ & $2 \mathrm{~B}$ & 0.20 \\
\hline 4 & $\begin{array}{l}\text { Yaroo Naowabad Road } \\
\text { Dera Ghazi Khan }\end{array}$ & $2 \mathrm{~B}$ & 0.22 \\
\hline 5 & Salgran Murree & 3 & 0.28 \\
\hline 6 & Rawalakot & 3 & 0.30 \\
\hline 7 & Bagh Kahuta Road Bagh, & 4 & 0.38 \\
\hline 8 & Muzaffarabad & 4 & 0.34 \\
\hline
\end{tabular}

The bridges were modelled in SAP2000 V14 software as per the available structural drawings. Material properties, i.e., concrete strength, yield strength for steel, and sectional properties, i.e., girders and piers, for each bridge were designated as per the existing drawings. For bridge footing as pier-piles the height of pier was taken after adding corresponding water channel scour depth while for bridges with group of piles or well foundation and pile caps, height of pier above pile cap was considered. Soil structure interaction was ignored. There were no parametric variations along the length of the bridges. The PGA intensity values for each bridge are allocated as per BCP 2007 PGA contours map. Therefore, the values of the seismic coefficients $\mathbf{C}_{\mathbf{a}}$ and $\mathbf{C}_{\mathbf{v}}$ against seismic zone factor $\mathrm{Z}$, were interpolated accordingly (Table 5). 
Table 5. Details of bridges selected for analysis in different seismic zones

\begin{tabular}{|c|l|c|c|c|c|c|c|}
\hline No. & \multicolumn{1}{|c|}{ Bridge Location } & $\begin{array}{c}\text { Number } \\
\text { of spans }\end{array}$ & $\begin{array}{c}\text { Span length } \\
\mathrm{m}(\mathrm{ft} .)\end{array}$ & $\begin{array}{c}\text { Number } \\
\text { of lanes }\end{array}$ & $\begin{array}{c}\text { Number of piers } \\
\text { in each bent }\end{array}$ & $\begin{array}{c}\text { Shape and size, m (ft.) } \\
\text { of each pier }\end{array}$ & $\begin{array}{c}\text { Height of pier } \\
\mathrm{m}(\mathrm{ft} .)\end{array}$ \\
\hline 1 & $\begin{array}{l}\text { Budhi Nullah near village } \\
\text { Daulatpur, Sargodha }\end{array}$ & 2 & $12.19(40)$ & 2 & 2 & circular, 0.838 (2.75) dia. & $9.146(30)$ \\
\hline 2 & Saggian Ravi River Lahore & 16 & $41.159(135)$ & 2 & 2 & circular, 1.829 (6) dia. & $35.671(117)$ \\
\hline 3 & $\begin{array}{l}\text { Dina-Rohtas Road near } \\
\text { Rohtas Fort }\end{array}$ & 7 & $31.512(103.36)$ & 2 & 2 & circular, 1.676 (5.5) dia. & $18.293(60)$ \\
\hline 4 & $\begin{array}{l}\text { Yaroo Naowabad Road } \\
\text { Dera Ghazi Khan }\end{array}$ & 5 & $14.78(48.5)$ & 2 & 2 & circular, 0.991 (3.25) dia. & $13.491(44.25)$ \\
\hline 5 & Salgran Murree & 3 & $30.488(100)$ & 2 & 2 & circular, 1.676 (5.5) dia. & $14.634(48)$ \\
\hline 6 & Rawalakot & 3 & $22.866(75)$ & 2 & 2 & circular, 1.676 (5.5) dia. & $15.854(52)$ \\
\hline 7 & Bagh Kahuta Road Bagh & 9 & $18.292(60)$ & 1 & 2 & circular, 0.991 (3.25) dia. & $3.963(13)$ \\
\hline 8 & Muzaffarabad & 3 & $40.009(131.23)$ & 2 & 1 & circular, 1.601 (5.25) dia. & $15.585(51.12)$ \\
\hline
\end{tabular}

\section{Modelling}

Modelling was done as per the structural drawings prepared by the concerned design office of Pakistan. Girders, Deck slabs, and diaphragms were defined in section modular. All the load combinations were taken from the WPCPHB (Highway Department, Government of West Pakistan Lahore, 1967). The existing bridges were designed as per the WPCPHB assuming seismic loads as $2 \%, 4 \%$, and $6 \%$ of dead loads for different foundation conditions. The effect of the live load was therefore ignored. The material properties used for the modelling of the existing bridge were according to the structural design data and the key details given in these designs. Girders, Piers, and transoms were modelled by using these details. The bearings on the pier head were considered as link elements, and bearings on the abutment sides were modelled as springs. The values of lateral, vertical, and rotational spring stiffness for elastomeric bearing pads on the abutment sides are shown in Table 6.

The structural details of key components of the existing bridges are as per drawings. After modeling all the components on SAP2000v14, perspective view of each $3-\mathrm{D}$ model is shown in Figure 8.

Table 6. Spring stiffness on the abutment sides

\begin{tabular}{|l|c|}
\hline \multicolumn{1}{|c|}{ Direction } & Spring stiffness, KN/m (K/ft) \\
\hline Lateral & $1755(120.256)$ \\
\hline Vertical & $1143752(78371.900)$ \\
\hline Rotational & $16270(1114.850)$ \\
\hline
\end{tabular}

\section{Analysis}

For analysis of these bridges, the soil profile type $S_{D}$ (stiff soil) was considered. The values of seismic coefficients $\mathbf{C}_{\mathbf{a}}$ and $\mathbf{C}_{\mathbf{v}}$ for seismic zone factor $\mathrm{Z}$, relevant to the soil profile type were taken as per BCP 2007. The structural ductility was considered by the Response modification factor (R) as per BCP 2007 Table 5.13. Static linear analysis as well as dynamic analysis considering Response Spectrum of UBC97 following BCP 2007 (Section 5.31.2 and Figure 5.1) were performed after applying the required inputs. Load combinations of WPCPHB were employed in the model. To check the capacity of the bridges, the factors of 1.25 , $1.33,1.40$ and 1.50 in load combinations of WPCPHB were reduced to 1.0 and SAP2000 model was run and the analysis results were then examined.

\subsection{Results and discussion}

Static linear as well as dynamic analysis were performed and the models were checked for elastic limits. From the analysis of the data obtained, it was observed that against the load combination, 1.0 Dead+1.0 Earthquake, which is a load case for seismic forces, the bridge piers in central spans had maximum flexure demands. The seismic base shear at the base of most vulnerable pier of each bridge are summarized below in Table 7 . It was noted that the average base shear was $9.07 \%$ of dead load for bridges in zone- $2 \mathrm{~A}$ and $21.22 \%, 23.73 \%$ and $40.07 \%$ for the bridges in zone $2 \mathrm{~B}, 3$ and 4 respectively. In the absence of national seismic code of Pakistan all the bridges were designed according to WPCPHB (Highway Department, Government of West Pakistan Lahore, 1967) where the seismic load was taken as $2 \%, 4 \%$ and $6 \%$ of dead loads for different foundation conditions as Pakistan lacked an indigenous seismic code for bridges. As the foundation type here in these cases is pile one, the seismic load in design was $6 \%$. The exaggerated seismic demand in case bridges is due to the application of seismic load as per BCP 2007 (Ministry of Housing and Works, 2007) PGA contour map and is summarized in Table 4.

The bridge models were then run for design as per UBC/ IBC requirements with dead load only and 1.0 Dead+1.0 Earthquake as design combinations. Here the earthquake loading was only from dynamic load case (Response Spectrum). It was noted that for most of the spans in central portions the piers displayed failure. The models were checked for flexure and shear design of bridge piers according to ACI 318-05 (ACI, 2004) for the applied seismic loadings and the additional demand for flexural steel was noted for the same pier sizes for revised seismic loadings and summarized in Table 8. Seven out of eight analysed bridges are thus under-designed and vulnerable in the existing seismic zones. 
a)

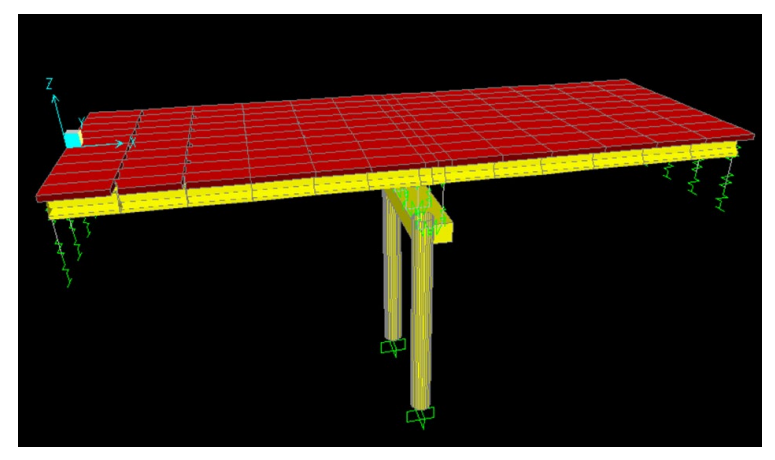

c)

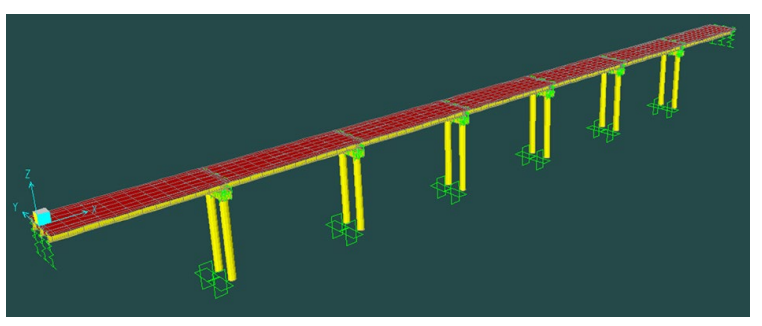

e)

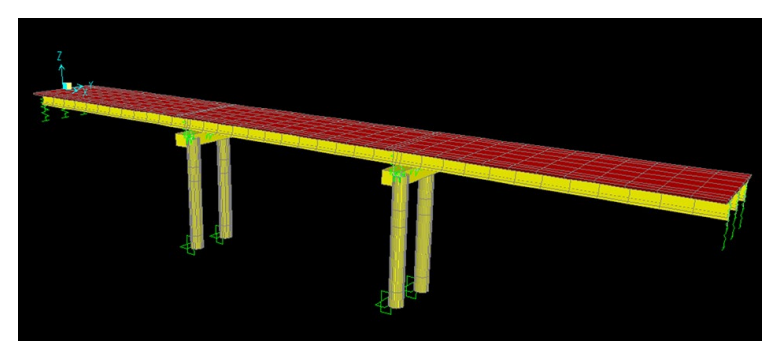

g)

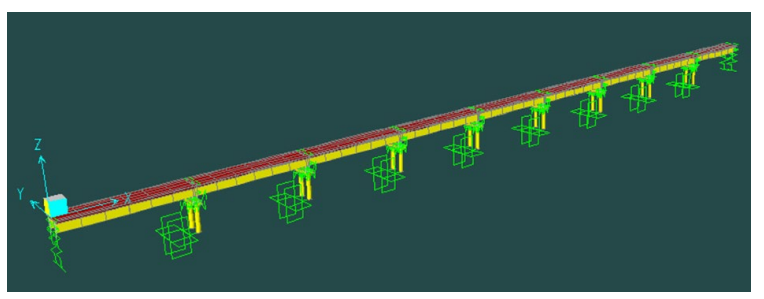

b)

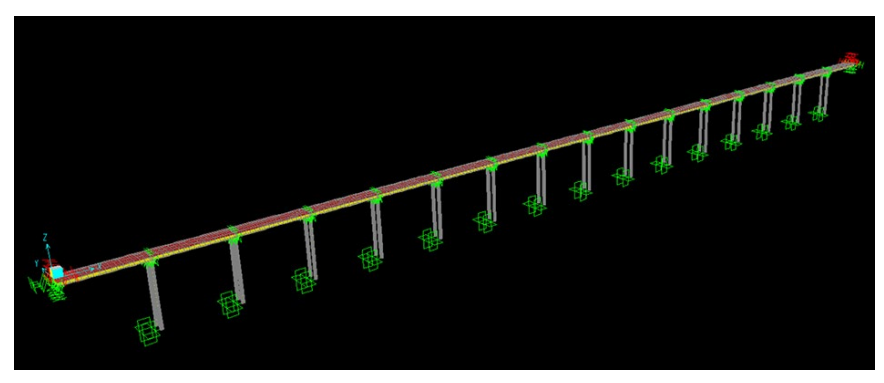

d)

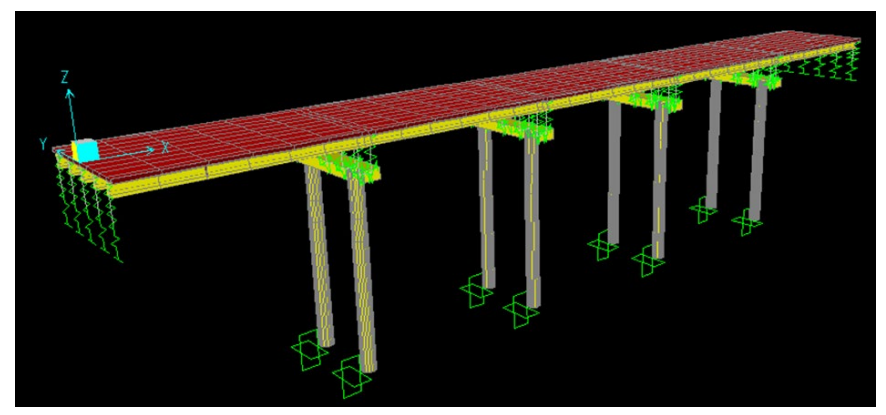

f)

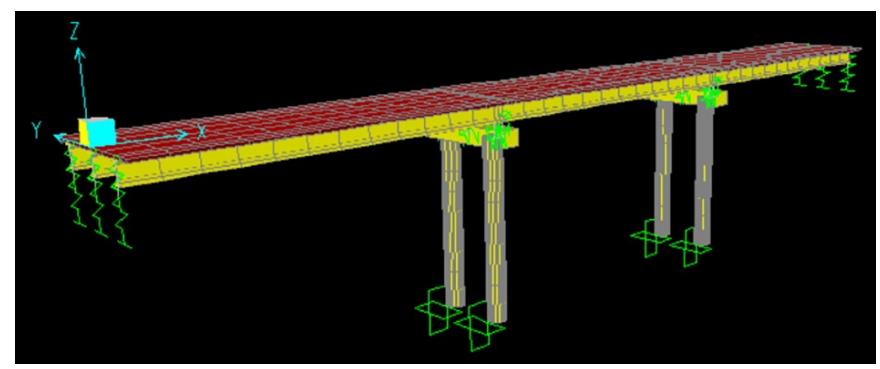

h)

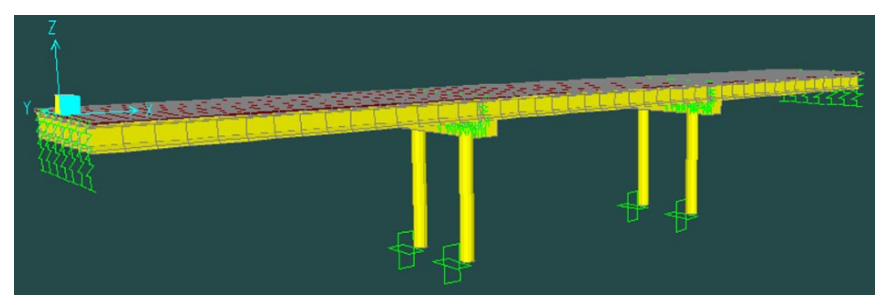

Figure 8. 3-D model View of SAP2000 V14 of each bridge: a - Budhi Nullah near village Daulatpur, Sargodha; b - Saggian Ravi River Lahore; c - Dina-Rohtas Road near Rohtas Fort; d - Yaroo Naowabad Road Dera Ghazi Khan; e - Salgran Murree; f - Rawalakot; g - Bagh Kahuta Road Bagh; h - Muzaffarabad

It is concluded that the seismic requirements of WPCPHB (Highway Department, Government of West Pakistan Lahore, 1967) do not match with the present seismic demand of the areas as per PGA estimated in BCP 2007. The bridges thus require additional measures to accommodate this extra demand and there is a need for retrofitting for all the critical members. To accommodate the required strength for critical members and to compensate for this gap provision of retrofitting through RC Jacketing is proposed.

\subsection{Seismic risk of existing bridge stock in Pakistan}

To investigate the seismic risk of the existing bridges a database of the existing RC bridges along the national highways has been prepared. The available data included information such as bridge location, type, number of spans and span length. This database of bridges is prepared to investigate the seismic risk according to latest seismic zoning map in Pakistan by comparing the demand and capacity. 
Table 7. Base shear for most critical piers

\begin{tabular}{|c|c|c|c|c|c|c|c|}
\hline \multirow{2}{*}{ No. } & \multirow{2}{*}{ Bridge location } & \multirow{2}{*}{$\begin{array}{l}\text { Dead Load } \\
\text { KN (kips) }\end{array}$} & \multirow{2}{*}{$\begin{array}{c}\text { Base Shear @ 6\% } \\
\text { of dead load, KN } \\
\text { (kips) }\end{array}$} & \multirow{2}{*}{$\begin{array}{c}\text { Base shear as per } \\
\text { analysis, EQY KN } \\
\text { (kips) }\end{array}$} & \multicolumn{2}{|c|}{$\begin{array}{c}\text { Base Shear @ \% of } \\
\text { dead load }\end{array}$} & \multirow{2}{*}{$\begin{array}{l}\text { Difference } \\
\text { KN (kips) }\end{array}$} \\
\hline & & & & & Each pier & Average & \\
\hline 1 & $\begin{array}{l}\text { Budhi Nullah near village } \\
\text { Daulatpur, Sargodha }\end{array}$ & $\begin{array}{c}950.12 \\
(213.596)\end{array}$ & $\begin{array}{c}57.007 \\
(12.816)\end{array}$ & $\begin{array}{c}83.409 \\
(18.751)\end{array}$ & 8.78 & \multirow[t]{2}{*}{9.07} & $\begin{array}{l}26.402 \\
(5.935)\end{array}$ \\
\hline 2 & Saggian Ravi River Lahore & $\begin{array}{c}5649.94 \\
(1270.158)\end{array}$ & $\begin{array}{c}338.99 \\
(76.209)\end{array}$ & $\begin{array}{c}529.83 \\
(136.752)\end{array}$ & 9.37 & & $\begin{array}{c}190.84 \\
(42.902)\end{array}$ \\
\hline 3 & $\begin{array}{l}\text { Dina-Rohtas Road near } \\
\text { Rohtas Fort }\end{array}$ & $\begin{array}{c}3356.26 \\
(754.517)\end{array}$ & $\begin{array}{c}201.38 \\
(45.271)\end{array}$ & $\begin{array}{c}710.747 \\
(159.782)\end{array}$ & 21.18 & \multirow[t]{2}{*}{21.22} & $\begin{array}{c}509.367 \\
(114.511)\end{array}$ \\
\hline 4 & $\begin{array}{l}\text { Yaroo Naowabad Road } \\
\text { Dera Ghazi Khan }\end{array}$ & $\begin{array}{c}1256.75 \\
(282.529)\end{array}$ & $\begin{array}{c}75.406 \\
(16.952)\end{array}$ & $\begin{array}{l}267.202 \\
(60.069)\end{array}$ & 21.26 & & $\begin{array}{l}191.796 \\
(43.117)\end{array}$ \\
\hline 5 & Salgran Murree & $\begin{array}{c}3344.97 \\
(751.979)\end{array}$ & $\begin{array}{c}200.69 \\
(45.118)\end{array}$ & $\begin{array}{c}814.376 \\
(183.075)\end{array}$ & 24.35 & \multirow[t]{2}{*}{23.73} & $\begin{array}{c}613.686 \\
(137.957)\end{array}$ \\
\hline 6 & Rawalakot & $\begin{array}{c}3407.97 \\
(766.143) \\
\end{array}$ & $\begin{array}{c}204.48 \\
(45.968)\end{array}$ & $\begin{array}{c}787.897 \\
(177.126) \\
\end{array}$ & 23.12 & & $\begin{array}{c}583.417 \\
(131.158) \\
\end{array}$ \\
\hline 7 & Bagh Kahuta Road Bagh & $\begin{array}{c}721.83 \\
(162.273)\end{array}$ & $\begin{array}{l}43.307 \\
(9.736)\end{array}$ & $\begin{array}{c}394.04 \\
(88.587)\end{array}$ & 54.59 & \multirow[t]{2}{*}{40.07} & $\begin{array}{l}350.733 \\
(78.851)\end{array}$ \\
\hline 8 & Muzaffarabad & $\begin{array}{l}3106.69 \\
(698.41)\end{array}$ & $\begin{array}{c}186.40 \\
(41.905)\end{array}$ & $\begin{array}{c}793.947 \\
(178.486)\end{array}$ & 25.56 & & $\begin{array}{c}607.547 \\
(136.581)\end{array}$ \\
\hline
\end{tabular}

Table 8. Longitudinal steel demand for most critical piers

\begin{tabular}{|c|c|c|c|c|c|c|c|c|}
\hline $\begin{array}{l}\text { Sr. } \\
\text { No. }\end{array}$ & $\begin{array}{l}\text { Bridge } \\
\text { Location }\end{array}$ & $\begin{array}{l}\text { Shape } \\
\text { and size, } \\
\mathrm{m}(\mathrm{ft} .) \text { of } \\
\text { each pier }\end{array}$ & $\begin{array}{l}\text { Longitudinal } \\
\text { steel provided } \\
\text { sq cm } \\
\text { (sq in.) }\end{array}$ & $\begin{array}{l}\text { Steel demand as } \\
\text { per new zoning } \\
\text { requirements sq } \\
\text { cm (sq in.) }\end{array}$ & $\begin{array}{l}\text { Deficiency } \\
\text { sq cm } \\
\text { (sq in.) }\end{array}$ & $\begin{array}{c}\text { Transverse/ } \\
\text { shear steel } \\
\text { provided } \\
\text { sq cm /m } \\
\text { (sq in./ ft) }\end{array}$ & $\begin{array}{c}\text { Shear steel } \\
\text { demand as } \\
\text { per analysis } \\
\text { sq cm/m } \\
\text { (sq in./ft) }\end{array}$ & Remarks \\
\hline 1 & $\begin{array}{l}\text { Budhi Nullah } \\
\text { near village } \\
\text { Daulatpur, } \\
\text { Sargodha }\end{array}$ & $\begin{array}{c}\text { circular, } \\
0.838 \\
(2.75) \mathrm{dia}\end{array}$ & $\begin{array}{l}57.226 \\
(8.87)\end{array}$ & $\begin{array}{l}54.827 \\
(8.495)\end{array}$ & $\begin{array}{c}0.00 \\
(0.00)\end{array}$ & $\begin{array}{c}7.98(0.377) \\
\# 3 @ 17.78(7) \\
\text { c/c spiral }\end{array}$ & Minimum & $\begin{array}{l}\text { The existing design } \\
\text { meets revised } \\
\text { seismic demands }\end{array}$ \\
\hline 2 & $\begin{array}{l}\text { Saggian Ravi } \\
\text { River Lahore }\end{array}$ & $\begin{array}{l}\text { circular, } \\
1.829 \\
\text { (6) dia }\end{array}$ & $\begin{array}{l}412.489 \\
(63.936)\end{array}$ & $\begin{array}{l}457.146 \\
(70.855)\end{array}$ & $\begin{array}{l}44.657 \\
(6.919)\end{array}$ & $\begin{array}{c}8.464(0.40) \\
\# 4 @ 30.5(12) \\
\text { c/c ties }\end{array}$ & Minimum & $\begin{array}{l}\text { Retrofitting } \\
\text { required to meets } \\
\text { revised seismic } \\
\text { demands }\end{array}$ \\
\hline 3 & $\begin{array}{l}\text { Dina-Rohtas } \\
\text { Road near } \\
\text { Rohtas Fort }\end{array}$ & \begin{tabular}{|c|} 
circular, \\
$1.676(5.5)$ \\
dia
\end{tabular} & $\begin{array}{l}263.064 \\
(40.755)\end{array}$ & $\begin{array}{l}317.717 \\
(49.246)\end{array}$ & $\begin{array}{l}54.653 \\
(8.491)\end{array}$ & $\begin{array}{c}4.655(0.22) \\
\# 3 @ 30.5(12) \\
\text { c/c ties }\end{array}$ & $\begin{array}{l}13.966 \\
(0.66)\end{array}$ & $\begin{array}{l}\text { Retrofitting } \\
\text { required to meets } \\
\text { revised seismic } \\
\text { demands }\end{array}$ \\
\hline 4 & \begin{tabular}{|l|} 
Yaroo \\
Naowabad \\
Road Dera \\
Ghazi Khan \\
\end{tabular} & $\begin{array}{c}\text { circular, } \\
0.991 \\
(3.25) \mathrm{dia}\end{array}$ & $61.161(9.48)$ & $\begin{array}{l}173.729 \\
(24.08)\end{array}$ & $\begin{array}{c}112.568 \\
(14.60)\end{array}$ & $\begin{array}{c}9.311(0.440) \\
\# 3 @ 15.25(06) \\
\text { c/c spiral }\end{array}$ & $\begin{array}{c}8.379 \\
(0.396)\end{array}$ & $\begin{array}{l}\text { Retrofitting } \\
\text { required to meets } \\
\text { revised seismic } \\
\text { demands } \\
\end{array}$ \\
\hline 5 & $\begin{array}{l}\text { Salgran } \\
\text { Murree }\end{array}$ & $\begin{array}{c}\text { circular, } \\
1.676 \\
(5.5) \mathrm{dia}\end{array}$ & $\begin{array}{c}214.064 \\
(33.18)\end{array}$ & $\begin{array}{l}266.329 \\
(41.281)\end{array}$ & $\begin{array}{l}52.265 \\
(8.101)\end{array}$ & $\begin{array}{c}12.69(0.60) \\
\# 4 @ 20.32(8) \\
\text { c/c ties }\end{array}$ & $\begin{array}{l}13.966 \\
(0.66)\end{array}$ & $\begin{array}{l}\text { Retrofitting } \\
\text { required to meets } \\
\text { revised seismic } \\
\text { demands }\end{array}$ \\
\hline 6 & Rawalakot & $\begin{array}{c}\text { circular, } \\
1.676 \\
(5.5) \text { dia }\end{array}$ & $\begin{array}{c}269.354 \\
(41.75)\end{array}$ & $\begin{array}{l}283.409 \\
(43.929)\end{array}$ & $\begin{array}{l}14.055 \\
(2.179)\end{array}$ & $\begin{array}{c}12.69(0.60) \\
\# 4 @ 20.32(8) \\
\text { c/c ties }\end{array}$ & $\begin{array}{l}13.966 \\
(0.66)\end{array}$ & $\begin{array}{l}\text { Retrofitting } \\
\text { required to meets } \\
\text { revised seismic } \\
\text { demands }\end{array}$ \\
\hline 7 & $\begin{array}{l}\text { Bagh Kahuta } \\
\text { Road Bagh }\end{array}$ & $\begin{array}{c}\text { circular, } \\
0.991 \\
(3.25) \text { dia }\end{array}$ & $\begin{array}{l}61.161 \\
(9.480)\end{array}$ & $\begin{array}{l}178.826 \\
(27.718)\end{array}$ & $\begin{array}{l}117.656 \\
(18.238)\end{array}$ & $\begin{array}{c}6.21(0.293) \\
\# 3 @ 22.86(9) \\
\text { c/c ties }\end{array}$ & $\begin{array}{c}13.712 \\
(0.648)\end{array}$ & $\begin{array}{l}\text { Retrofitting } \\
\text { required to meets } \\
\text { revised seismic } \\
\text { demands }\end{array}$ \\
\hline 8 & Muzaffarabad & $\begin{array}{c}\text { circular, } \\
1.601 \\
(5.25) \text { dia }\end{array}$ & $\begin{array}{c}244.645 \\
(37.92)\end{array}$ & $\begin{array}{l}304.833 \\
(47.249)\end{array}$ & $\begin{array}{l}60.188 \\
(9.377)\end{array}$ & $\begin{array}{c}12.697(0.60) \\
\# 4 @ 20.32(8) \\
\text { c/c ties }\end{array}$ & $\begin{array}{l}13.458 \\
(0.636)\end{array}$ & $\begin{array}{l}\text { Retrofitting } \\
\text { required to meets } \\
\text { revised seismic } \\
\text { demands }\end{array}$ \\
\hline
\end{tabular}


The available bridge data scattered across Pakistan after super imposing on BCP 2007 Seismic Zoning map is shown in Figure 1. It can be clearly seen that majority of the bridges lies in zone $2 \mathrm{~A}(0.08 \mathrm{~g}-0.16 \mathrm{~g})$ and zone 2B ( $0.08 \mathrm{~g}-0.24 \mathrm{~g})$. Relatively few bridges exist in zone 3 $(0.24 \mathrm{~g}-0.32 \mathrm{~g})$ and zone $4(\geq 0.32 \mathrm{~g})$ in the western and southern regions. The bridges of the northern region are also mainly in zone 3 and few are in zone 4 . The seismic capacity of typical selected bridges is calculated according to $6 \%$ seismic load as well as with respect to the actual zonal requirements. The capacity of seven out of eight studied bridges is less than the requirement as per the PGA for corresponding zone. It was noted that the average base shear was $9.07 \%$ of dead load for bridges in zone- $2 \mathrm{~A}$ and $21.22 \%, 23.73 \%$ and $40.07 \%$ for the bridges in zone $2 \mathrm{~B}, 3$ and 4 respectively. The deficiency of longitudinal steel demand for the bridge piers was less in zone $2 \mathrm{~A}$ and high in zone 4.

If this design capacity is generalized it can be concluded that the bridges in zone $2 \mathrm{~A}$ are generally less vulnerable and bridges exist in this zone are in a low risk zone. Whereas the bridges that exist in zone $2 \mathrm{~B}, 3$ and 4 are vulnerable from medium to very high range. The detailed in-depth vulnerability study, considering the time histories based on the real earthquake events and other variables, of all bridge stock in high-risk zones needs to be made on priority and appropriate seismic retrofitting schemes require to be proposed.

\section{Conclusions}

Different researchers have performed peak Ground Acceleration (PGA) value studies for Pakistan using faults sources. The values given by each researcher differ from those of Building Code of Pakistan (BCP) with diverse standard deviations for different cities of Pakistan. The recent history shows the occurrence of major earthquake events in Pakistan area. The results of seismic hazard studies indicate that BCP requires an in depth revision considering micro and macro level investigations in Pakistan. The recent earthquakes in Pakistan also showed damages in bridges and some studies has been done by different researchers to investigate the capacity requirements of existing bridges in new seismic demands. The above studies and survey indicate that the seismic demands at many places in Pakistan are higher than those given in BCP 2007. Thus there is the requirement for investigation of all existing bridges, especially constructed before 2005, to check the capacity of the structure at least as per seismic zoning of BCP 2007.

The most of bridge stock in Pakistan has been designed assuming seismic loads as $2 \%, 4 \%$ and $6 \%$ of dead loads for different foundation conditions. The bridge stock is mostly of reinforced concrete. The capacity of eight selected real bridges, two for each seismic zone 2A, 2B, 3 \&4, designed following WPCPHB (Highway Department, Government of West Pakistan Lahore, 1967), was checked with respect to BCP 2007 seismic zoning maps. Static and dynamic analyses were performed and the piers being most vulnerable part of a bridge were checked for elastic limits. It is established that the piers, which have been designed for the base shear (6\% of dead load), are on lower side in capacity in comparison to the present BCP 2007 seismic zoning requirements. The placement of the available bridge stock inventory on the BCP map depicts those bridges in zone $2 \mathrm{~A}$ are generally less vulnerable and this zone is a low risk zone for existing bridges. Whereas the bridges that exist in zone 2B, 3 and 4 are vulnerable from medium to very high level. Hence, a detailed in-depth analytical vulnerability study, considering the time histories based on the real earthquake events and other variables, of the bridge stock particularly in high-risk zone needs to be conducted on priority and appropriate seismic retrofitting schemes need to be proposed.

\section{Acknowledgements}

Authors acknowledge, thank, and pay gratitude to the staff of Earthquake Reconstruction and Rehabilitation Authority Islamabad and Bridge Directorate, Planning and Design Department, Lahore, Pakistan for their technical guidance and support during research work.

\section{Funding}

This work was not supported by any funding agency.

\section{Author contributions}

Muhammad Khalid Hafiz conceived the study, collected and analyzed the data and wrote first draft of the research. Qaiser-uz-Zaman Khan designed and supervised the research, Sohaib Ahmad was responsible for monitoring of the data analysis and finalized the draft.

\section{Disclosure statement}

Authors declare that they do not have any competing financial, professional, or personal interests from other parties.

\section{References}

Ali, S. M., Khan, A. N., Rehman, S., \& Reinhorn, A. M. (2011). A survey of damages to bridges in Pakistan after the major earthquake of 8 October 2005. Earthquake Spectra, 27(4), 947-970. https://doi.org/10.1193/1.3650477

American Concrete Institute. (2004). Building code requirements for structural concrete and commentary (ACI 318-05). USA.

American Institute of Steel Construction. (2005). Seismic provisions for structural steel buildings (ANSI/AISC 341-05). USA.

American Society of Civil Engineers. (1994). Minimum design loads for buildings and other structures (ANSI/ASCE 7-93). USA.

American Society of Civil Engineers. (2006). Minimum design loads for buildings and other structures (ASCE/SEI 7-05). USA. 
Earthquake Reconstruction and Rehabilitation Authority. (2006a). Annual review 2005-2006. Prime Minister Secretariat (Public), Islamabad, Pakistan.

Earthquake Reconstruction and Rehabilitation Authority. (2006b). "Build back better" reconstruction and rehabilitation strategy, transport (roads \& bridges) sector. Prime Minister Secretariat (Public), Islamabad, Pakistan.

Economic Adviser's Wing, Finance Division. (2019). Pakistan economic survey 2018-2019. Government of Pakistan, Islamabad, Pakistan.

Global Seismic Hazard Assessment Program. (1999). http://www.seismo.ethz.ch/GSHAP/

Hashash, Y. M. A., Kim, B., Olson, S. M., \& Ahmad, I. (2012). Seismic hazard analysis using discrete faults in Northwestern Pakistan: Part I - methodology and evaluation. Journal of Earthquake Engineering, 16, 963-994. https://doi.org/10.1080/13632469.2012.681423

Highway Department, Government of West Pakistan Lahore. (1967). Code of practice, highway bridges.

Information Management and Mine Action Programs. (2013). Earthquake 2013 atlas of Balochistan: Districts Awaran, Kech, Panjgur, Khuzdar, \& Washuk. Islamabad, Pakistan.

International Conference of Building Officials. (1997). Uniform building code. California, USA.

Khan, R. A., Kumar, M., Ahmed, M., Rafi, M. M., \& Lodi, S. H. (2015). Earthquake damage assessment of bridges in Karachi. NED University Journal of Research, 12(3), 45-61.

Khan, S. A., Pilakoutas, K., Hajirasouliha, I., Guadagnini, M., Mulyani, R., Ahmadi, R., \& Elwaeli, W. (2017). Seismic risk assessment for developing countries: Pakistan as a case study. Earthquake Engineering and Engineering Vibration, 17(4), 787-804. https://doi.org/10.1007/s11803-018-0476-3

Ministry of Housing and Works. (2007). Building code of Pakistan $(B C P)$. Government of Pakistan, Islamabad.

MonaLisa, Khwaja, A. A., \& Jan, M. Q. (2007). Seismic hazard assessment of the NW Himalayan Fold-and-Thrust Belt, Pakistan, using probabilistic approach. Journal of Earthquake Engineering, 11, 257-301.

https://doi.org/10.1080/13632460601031243

National Disaster Management Authority. (2019). Mirpur Earthquake 2019 (Situation report No. 08). Islamabad, Pakistan.

Pakistan Meteorological Department, \& NORSAR (Norway). (2006). Seismic hazard analysis and zonation for the northern areas of Pakistan and Kashmir.

Pakistan Meteorological Department, \& NORSAR (Norway). (2007). Seismic hazard analysis and zonation for Pakistan, Azad Jammu and Kashmir.

Pakistan Meteorological Department. (2019). Seismicity map. National Seismic Monitoring Centre Islamabad, Pakistan. http://seismic.pmd.gov.pk/seismicity-maps.php

Quittmeyer, R., \& Jacob, K. H. (1979). Historical and modern seismicity of Pakistan, Afghanistan, northwestern India, and southeastern Iran. Bulletin of the Seismological Society of America, 69(3), 773-823.

Rafi, Z., Ahmed, N., Ur-Rehman, S., Azeem, T., \& Abd el-aal, A. e. K. (2013). Analysis of Quetta-Ziarat earthquake of 29 October 2008 in Pakistan. Arabian Journal of Geosciences, 6, 1731-1737. https://doi.org/10.1007/s12517-011-0485-2

Shah, B. A., Sadiq, M. M., Memon, S. A., \& Rehman, S. K. U. (2021). Assessment of the seismicity of Peshawar region in line with the historical data and modern building codes (ASCE-07 \& IBC-2006). Journal of Earthquake Engineering, 25(9), 1826-1850.

https://doi.org/10.1080/13632469.2019.1605315
USGS Earthquake Hazards Program. (2020). Maps. https://earthquake.usgs.gov/earthquakes/eventpage/usb000jyiv/executive

Waseem, M., \& Spacone, E. (2017). Fragility curves for the typical multi-span simply supported bridges in northern Pakistan. Structural Engineering \& Mechanics, 64(2), 213-223.

Waseem, M., Khan, M. A., \& Khan, S. (2019). Seismic sources for southern Pakistan and seismic hazard assessment of Karachi. Natural Hazards, 99(1), 511-536. https://doi.org/10.1007/s11069-019-03755-5

Waseem, M., Khan, S., \& Khan, M. A. (2020). Probabilistic seismic hazard assessment of Pakistan territory using an aerial source model. Pure and Applied Geophysics, 177, 3577-3597. https://doi.org/10.1007/s00024-020-02455-7

Water and Power Development Authority. (2015). Simly dam project seismotectonics \& seismic hazard analysis (Technical Report by Directorate of Seismic Studies office of the General Manager \& Project Director Tarbela Dam Project, Vol. 1). Pakistan.

Zaman, S., Ornthammarath, T., \& Warnitchai, P. (2012). Probabilistic seismic hazard maps for Pakistan. In 15th World Conference on Earthquake Engineering (pp. 8677-8687), Lisbon, Portugal. 